\title{
PENGEMBANGAN LKPD BERBASIS ICARE (INTRODUCTION, CONNECT, APPLY, REFLECT, EXTEND) PADA MATERI PENENTUAN PERUBAHAN ENTALPI UNTUK SMA/MA
}

Endah Tri Handayani ${ }^{1 *}$, Herdini ${ }^{2}$, Susilawati ${ }^{3}$

Program Studi Pendidikan Kimia Fakultas Keguruan dan IImu Pendidikan

Universitas Riau

*Email: endahtri382@gmail.com

\begin{abstract}
Abstrak
Penelitian ini bertujuan untuk mengembangkan Lembar Kegiatan Peserta didik (LKPD) berbasis ICARE pada materi penentuan perubahan entalpi untuk kelas XI SMA/MA yang valid berdasarkan aspek kelayakan isi, kekarakteristikan ICARE, kebahasaan, penyajian dan kegrafisan. Jenis penelitian ini adalah penelitian pengembangan (Research \& Development) dengan proses pengembangan mengacu kepada model pengembangan Plomp. Objek penelitian ini berupa LKPD berbasis ICARE. Instrumen pengumpulan data berupa lembaran validasi yang diisi oleh 3 orang validator, hasil analisis data didapatkan skor validitas dari aspek kelayakan isi, karakteristik ICARE, kebahasaan, penyajian dan kegrafisan berturut- turut yaitu 92,59\%, 96,67\%,95\%, 97,22\%, dan $95,83 \%$ dengan kategori valid. LKPD yang sudah valid bagi validator diujicobakan terhadap 20 orang peserta didik dan diperoleh hasil respon dengan skor 3,45 dengan kriteria sangat baik, serta 3 orang guru dan diperoleh skor 3,6 dengan kriteria sangat baik. Berlandaskan hasil analisis data diperoleh kesimpulan bahwa LKPD berbasis ICARE yang dikembangkan valid dan bisa diterapkan dalam proses pembelajaran pada materi penentuan perubahan entalpi.
\end{abstract}

Kata Kunci : Penentuan Perubahan Entalpi, LKPD, ICARE.

Abstract

This Research aims to develop Student Activity Worksheet (LKPD) based on ICARE of determination of the enthalpy changes subject for class XI SMA/MA valid based on content feasibilities, characteristics ICARE, linguistic, presentation, and graphics. The type of this research is development research (Research and Development) with the process referring to the plomp development model. The object of this research is LKPD based on ICARE. Data collection instruments was a validation sheets filled by 3 validators, the results of the validity data analysis of feasibility aspect of content, characteristics of ICARE, language, presentation and graphics are 92,59\%, 96,67\%, 95\%, 97,22\%, and 95,83\% with valid category. LKPD that has been valid by validators was tested on 20 students and got response results with score 3,45 with very good criteria, and 3 teachers got response result with score 3,6 with very good criteria. From results of analysis data can conclusion that LKPD based on ICARE developed was valid and can be applied for determination of the enthalpy changes subject.

Keywords : Enthalpy Changes, Student Worksheets, ICARE.

\section{PENDAHULUAN}

Pembelajaran merupakan suatu proses yang memerlukan langkah-langkah sistematis untuk mencapai tujuan yang telah ditentukan. Pada pembelajaran kimia kualitas pembelajaran dan ketercapaian tujuan pembelajaran sangat dipengaruhi oleh beberapa faktor, salah satunya yaitu dalam penggunaan bahan ajar. Menurut Prastowo (2013) bahan ajar mempunyai fungsi penting dalam proses pembelajaran, misalnya buku pelajaran, modul, handout, Lembar Kegiatan Peserta Didik (LKPD) 
dan sebagainya. Bahan ajar yang dapat dikembangkan oleh guru salah satu diantaranya dapat berupa LKPD.

Hasil wawancara dengan guru kimia di MA Muhammadiyah Pekanbaru diperoleh informasi bahwa bahan ajar yang digunakan peserta didik selama ini merupakan Lembar Kerja Siswa (LKS) yang berasal dari penerbit. Materi pelajaran kimia kelas XI yang dianggap sulit adalah penentuan perubahan entalpi karena menuntut pemahaman konsep dan analisis yang tinggi dalam menyelesaikan soalsoalnya serta terampil dalam perhitungan. Permasalahan pembelajaran tersebut ialah diperlukannya pengembangan terhadap LKPD yang bisa membangun peserta didik menemukan konsep materi pembelajaran secara mandiri dan kegiatan mengaplikasikan pengetahuan peserta didik sesuai kurikulum 2013.

Langkah yang dapat ditempuh yaitu dengan mengembangkan LKPD berbasis ICARE (Introduction, Connect, Apply, Reflect, Extend). Model pembelajaran ICARE adalah salah satu model pembelajaran yang menekankan pada penanaman konsep dan kegiatan mengaplikasikan pengetahuan peserta didik. Peserta didik dibimbing untuk membangun sendiri pengetahuannya melalui tahap introduction dan connect, lalu mereka dapat membuktikan kebenaran dari pengetahuan yang telah mereka bangun pada tahap apply, kemudian peserta didik merefleksikan pengetahuan yang telah mereka peroleh pada tahap reflect dan pada tahap akhir yaitu extend peserta didik diberi kesempatan untuk belajar lebih luas agar pemahaman mereka tentang materi pembelajaran lebih kuat (Almubarak \& Hikmah, 2019). Model pembelajaran ICARE juga memilliki beberapa kelebihan diantaranya yaitu: (1) Pemetaan struktur isi yang seimbang antar teori dan praktek bagi guru dan peserta didik; (2) Memiliki pendekatan berbasis life skill; (3) Memungkinkan sekolah melakukan monitoring dan evaluasi yang terbuka kepada gurunya; (4) Memberikan kesempatan kepada guru untuk melakukan apersepsi pada setiap pembelajaran yang akan dilakukan dengan mudah (Wahyudin, 2010).

Penelitian yang relevan terkait dengan judul Pengembangan Lembar Kerja Siswa (LKS) berbasis ICARE pada mata pelajaran matematika siswa yang dilakukan oleh Suryanti dan Asrullah (2019) menyimpulkan bahwa tingkat kelayakan lembar kerja siswa sebesar 86,67\% (sangat tinggi). Hal ini menunjukan bahwa LKS layak digunakan pada proses pembelajaran. Berdasarkan latar belakang masalah yang sudah dipaparkan, peneliti tertarik untuk melaksanakan penelitian yang berjudul "Pengembangan LKPD Berbasis ICARE (Introduction, Connect, Apply, 
Reflect, Extend) pada Materi Penentuan Perubahan Entalpi untuk SMA/MA". Adapun LKPD berbasis ICARE yang dikembangkan oleh peneliti memilliki tampilan yang menarik dan dalam penyajian materi dikaitkan dengan kehidupan sehari-hari, sehingga peserta didik lebih mudah untuk memahami materi yang disajikan.

\section{METODE PENELITIAN}

Penelitian dilakukan di MA Muhammadiyah Pekanbaru dan SMAN 5 Pekanbaru. LKPD berbasis ICARE pada materi penentuan perubahan entalpi dikembangkan menggunakan metode Research and Development disingkat dengan $R$ and $D$, dengan model pengembangan yang digunakan adalah model Plomp meliputi 3 fase; fase penelitian pendahuluan (prelimenary research phase), fase pembuatan prototipe (prototyping phase), dan fase penilaian (assessment phase) (Plomp, 2013). Peneliti memilih model Plomp sebagai model prosedural dalam penelitian ini karena model Plomp memiliki tahapan atau langkah-langkah yang sistematis dan jelas untuk menghasilkan suatu produk (Rochmad, 2012). Penelitian yang dilaksanakan peneliti hanya sebatas mengembangkan LKPD dan menguji kelayakan LKPD berdasarkan kelima aspek kelayakan meliputi kelayakan isi, karakteristik ICARE, kebahasaan, penyajian dan kegrafisan sehingga dinyatakan valid oleh validator. Selanjutnya dilaksanakan uji respon pengguna dengan responden guru kimia dan peserta didik yang telah mempelajari materi penentuan perubahan entalpi. 


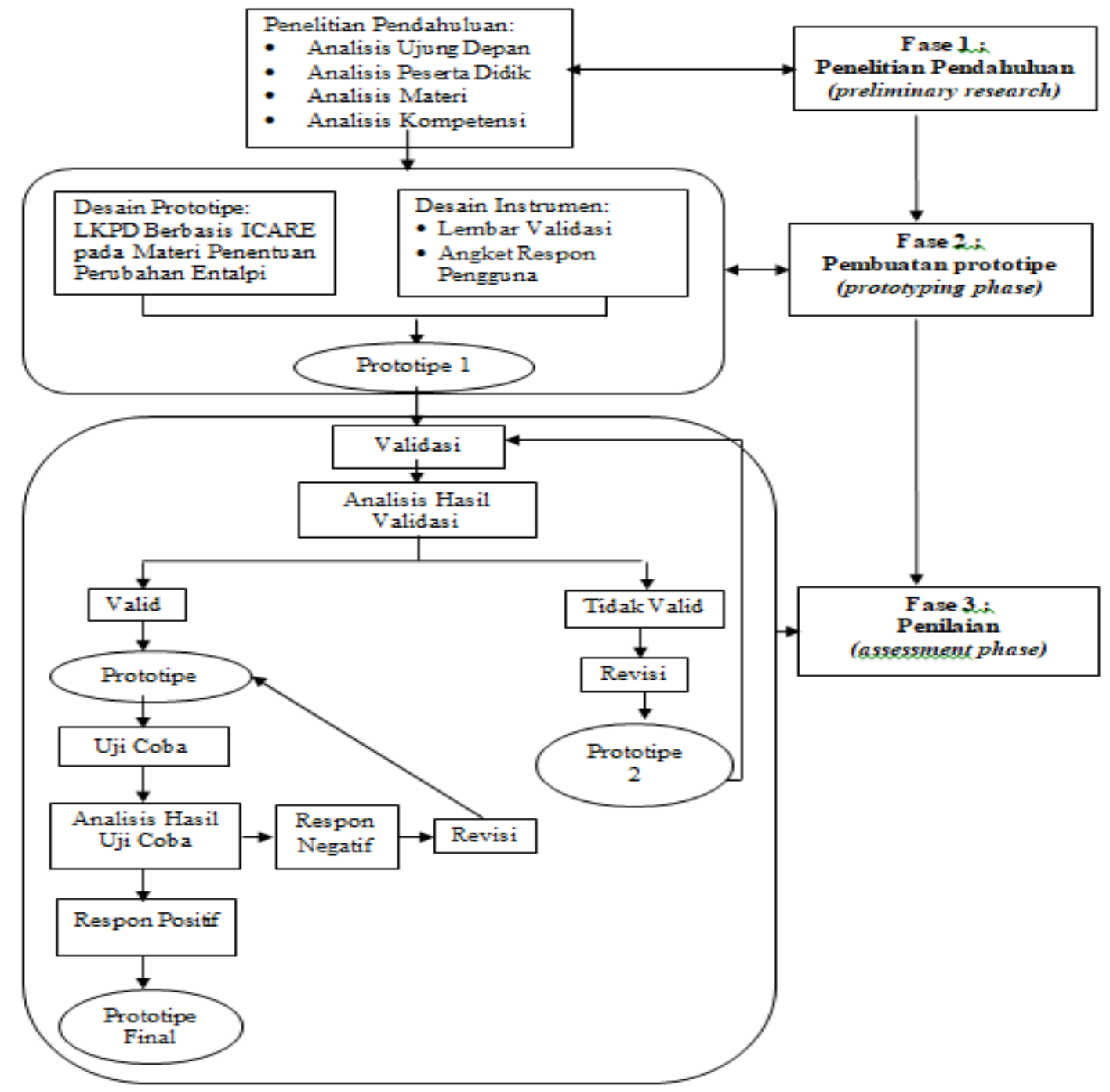

Gambar 1. Alur Pengembangan Plomp untuk LKPD Berbasis ICARE pada Materi Penentuan Perubahan Entalpi untuk Kelas XI SMA/MA Sederajat (Modifikasi Rawa, dkk., 2016)

Teknik pengumpulan data pada penelitian ini terkait validitas dan respon pengguna terhadap LKPD berbasis ICARE pada materi penentuan perubahan entalpi yang didapat dari fase penilaian yaitu validasi, revisi dan uji coba dengan instrumen penelitian berupa lembar validasi beserta rubrik, angket respon guru dan angket respon peserta didik.

Data yang dikumpulkan kemudian dilaksanakan teknik analisis tertentu. Analisis Validitas menggunakan rumusan oleh Riduwan (2012):

$$
\text { Persentase nilai validasi }=\frac{\text { Skor yang diperoleh }}{\text { Skor Maksimum }} \times 100 \%
$$

Persentase yang diperoleh kemudian dikonversi menjadi nilai kualitatif dengan kriteria validitas disajikan Tabel 1. 
Tabel 1. Kriteria Validitas

\begin{tabular}{cc}
\hline Persentase & Keterangan \\
\hline $80,00-100$ & Valid \\
$60,00-79,99$ & Cukup Valid \\
$50,00-59,99$ & Kurang Valid \\
$0-49,99$ & Tidak Valid \\
\hline
\end{tabular}

(Riduwan, 2012)

Analisis respon pengguna menggunakan skala Likert dengan pedoman penskoran dalam Tabel 2.

Tabel 2. Pedoman Penskoran Pernyataan Positif

\begin{tabular}{cc}
\hline Pernyataan Sikap & Skor \\
\hline Sangat Setuju (SS) & 4 \\
Setuju (S) & 3 \\
Kurang Setuju (KS) & 2 \\
Tidak Setuju (TS) & 1 \\
\hline
\end{tabular}

(Sugiyono, 2017)

Respon guru menggunakan rumusan oleh Supangat (2014):

Keterangan:

$$
\bar{x}=\frac{\sum x_{i}}{N}
$$

$\bar{x}=$ Rata-rata skor

$\sum x_{i}=$ Jumlah skor yang didapat

$N=$ Jumlah pernyataan

Persentase yang didapat dikonversi menjadi nilai kualitatif menggunakan kriteria respon disajikan Tabel 3.

Tabel 3. Kriteria Respon Pengguna

\begin{tabular}{cc}
\hline Rata-Rata Skor & Kriteria Respon Pengguna \\
\hline $3,25-4,00$ & Sangat Baik \\
$2,50-3,24$ & Baik \\
$1,75-2,49$ & Tidak Baik \\
$1,00-1,74$ & Sangat Tidak Baik \\
\hline
\end{tabular}

(Widoyoko, 2017)

\section{HASIL DAN PEMBAHASAN}

Penelitian pengembangan ini menghasilkan produk yaitu Lembar Kegiatan Peserta Didik (LKPD) berbasis ICARE pada materi penentuan perubahan entalpi untuk kelas XI SMA/MA yang sudah divalidasi. LKPD berbasis ICARE ini bisa diterapkan dalam kelas maupun sebagai bahan ajar mandiri saat di luar jam sekolah. 
Berikut pemaparan hasil dan pembahasan dari setiap fase model Plomp yang telah dilakukan.

\section{Fase Penelitian Pendahuluan}

\section{a. Analisis Ujung Depan}

Hasil analisis ujung depan yaitu belum terdapat LKPD berbasis ICARE yang memfasilitasi peserta didik untuk menemukan dan membangun konsep sendiri pada materi penentuan perubahan entalpi. Berdasarkan pengamatan dan hasil wawancara peneliti dengan guru kimia di MA Muhammadiyah Pekanbaru, diperoleh informasi bahwa dalam proses pembelajaran guru masih menggunakan LKS yang didapat dari penerbit. LKS tersebut dilihat dari segi isi dan penyajiannya belum mencakup syarat didaktik, konstruksi, dan teknis.

\section{b. Analisis Peserta Didik}

Peserta didik yang mempelajari materi penentuan perubahan entalpi pada umumnya memiliki rentang usia 16-18 tahun, yakni berada pada tahap operasional formal, berlandaskan kepada teori perkembangan kognitif Piaget. Pada tahap ini peserta didik sudah dapat membuat kesimpulan, serta menafsirkan dan menyusun suatu hipotesa. Namun, peserta didik masih sulit untuk menerima ilmu dengan konsep abstrak karena kurangnya pengalaman sehingga membatasi kecakapannya untuk memanfaatkan apa yang diketahui. Dari hasil wawancara diperoleh informasi bahwa konsep-konsep materi yang abstrak seperti penentuan perubahan entalpi masih sulit dipahami oleh peserta didik.

\section{c. Analisis Materi}

Analisis materi merupakan telaah untuk memilih dan menetapkan, merinci dan menyusun secara sistematis materi yang relevan untuk diajarkan. Pada materi penentuan perubahan entalpi peserta didik mempelajari penentuan perubahan entalpi secara kalorimetri, hukum Hess, data entalpi pembentukan standar, dan data energi ikatan. Materi yang dipilih dalam penelitian ini adalah penentuan perubahan entalpi. Prasyarat yang harus dipenuhi sebelum mempelajari materi penentuan perubahan entalpi ini adalah memahami konsep eksoterm-endoterm dan ikatan kovalen.

\section{d. Analisis Kompetensi}

Analisis kompetensi dilakukan untuk menelaah kompetensi sikap, pengetahuan dan keterampilan yang diharapkan dimiliki oleh peserta didik setelah 
mengikuti pembelajaran penentuan perubahan entalpi terhadap silabus mata pelajaran kimia SMA/MA oleh Kementrian Pendidikan dan Kebudayaan. Hasil dari analisis kompetensi tersebut diperoleh rumusan indikator pencapaian kompetensi yang telah dirumuskan berdasarkan Kompetensi Dasar (KD 3.5 dan 4.5).

\section{Fase Pembuatan Prototipe}

Penyusunan LKPD memperoleh komponen LKPD yang mencakup (1) Cover LKPD; (2) Daftar isi; (3) Petunjuk penggunaan LKPD; (4) Pembelajaran, yang terdiri dari; a) KD, b) TP, c) IPK, d) Uraian materi, yang memuat; informasi pendukung, contoh soal, latihan soal, dan lembar kesimpulan, e) Daftar pustaka. Instrumen validasi LKPD berupa lembar validasi dan rubrik validasi serta angket respon pengguna oleh guru dan peserta didik.

\section{Fase Penilaian}

Validasi LKPD

Validasi LKPD telah dilaksanakan kepada tiga orang validator ahli materi yang terdiri dari dua orang Dosen Pendidikan Kimia Universitas Riau dan satu orang dosen Kimia Universitas Muhammadiyah Riau sebanyak dua kali pada masingmasing validator. Setiap validator mengisi lembar validasi yang telah disusun berdasarkan aspek kelayakan isi, karakteristik ICARE, kebahasaan, penyajian dan kegrafisan. Penilaian validasi tim ahli materi terhadap lima aspek kelayakan LKPD dapat dilihat pada Tabel 4 berikut.

Tabel 4. Penilaian Kelima Aspek Kelayakan LKPD

\begin{tabular}{lccc}
\hline No & Aspek yang Dinilai & $\begin{array}{c}\text { Skor Rata- Rata } \\
\text { Validasi }\end{array}$ & Kategori \\
\hline 1 & Kelayakan Isi & $92,59 \%$ & Valid \\
2 & Kelayakan Karakteristik ICARE & $96,67 \%$ & Valid \\
3 & Kelayakan Kebahasaan & $95 \%$ & Valid \\
4 & Kelayakan Penyajian & $97,22 \%$ & Valid \\
5 & Kelayakan Kegrafisan & $95,83 \%$ & Valid \\
\hline \multicolumn{2}{c}{ Persentase Skor Rata-rata } & $95,46 \%$ & Valid \\
\hline
\end{tabular}

Skor rata-rata penilaian kelima aspek kelayakan LKPD oleh tim validator berturut-turut memiliki nilai kelayakan 92,59\%; 96,67\%; 95\%; 97,22\%; dan 95,83\%. Berdasarkan kriteria validitas pada Tabel 1 maka termasuk kategori valid. Diagram 
batang skor rata-rata penilaian validasi LKPD dari berbagai aspek disajikan pada Gambar 2.

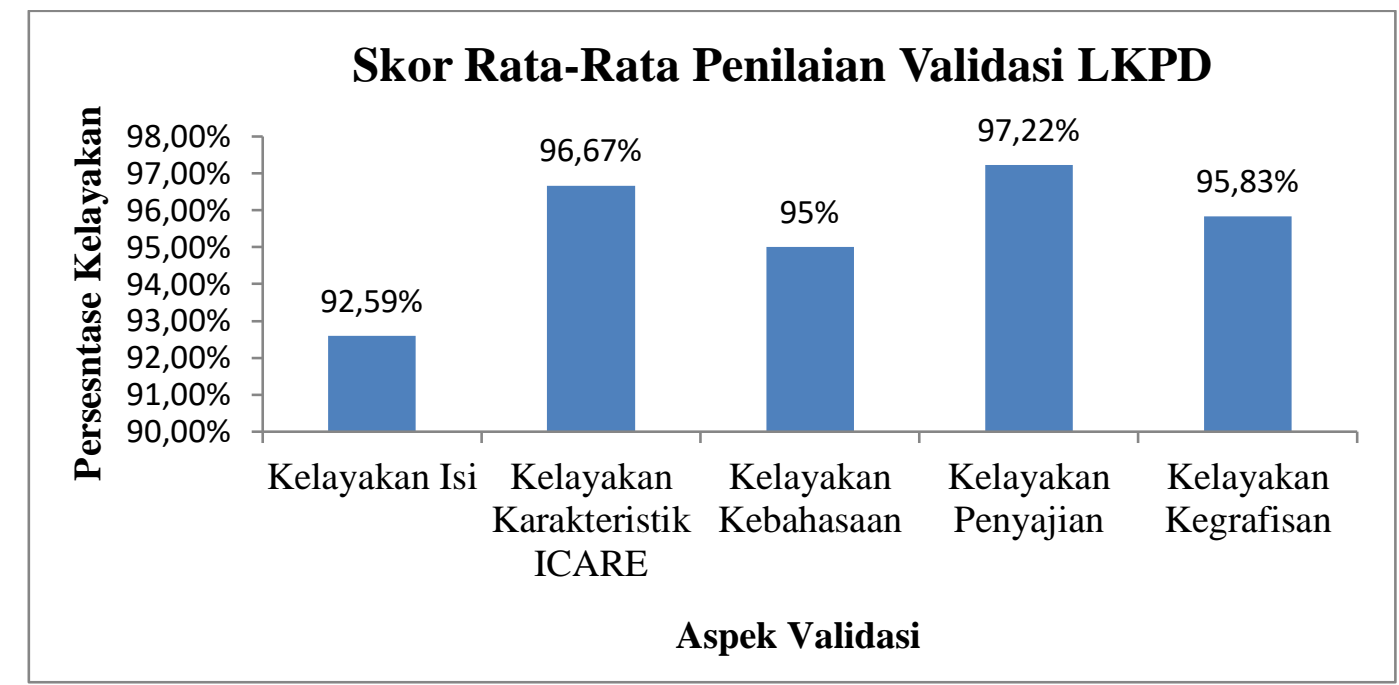

Gambar 2. Diagram batang skor rata-rata penilaian validasi LKPD

LKPD berbasis ICARE pada materi penentuan perubahan entalpi yang telah direvisi sesuai dengan saran dan masukan dari validator mendapatkan skor ratarata keseluruhan validasi sebesar 95,46\%. Skor yang diperoleh lebih tinggi jika dibandingkan dengan skor penelitian relevan yang dilakukan oeh Suryanti dan Muh Asrullah (2019) sebesar 86,67\%. Berdasarkan kriteria validitas dalam Riduwan (2012), maka kriteria validitas LKPD termasuk kategori valid.

Revisi

Revisi LKPD merupakan perbaikan LKPD berdasarkan saran dan masukan dari validator selama proses validasi berlangsung. Revisi dilakukan hingga didapatkan LKPD yang valid. Validator memberikan masukan yang sangat membantu dalam penyempurnaan LKPD yang dikembangkan oleh peneliti. Beberapa contoh hasil revisi yang dilakukan selama proses validasi dapat dilihat pada Gambar 3. dan 4.

Tampilan yang direvisi oleh validator ahli materi pada aspek kegrafisan terkait jenis dan ukuran font yang tidak seragam serta penulisan rumus kimia dan reaksi kimia yang tidak sesuai disediakan pada Gambar 3. Berikut : 


\section{Application (Mengaplikasi)}

Untuk lebih memahami cara penentuan perubahan entalpi $(\mathrm{LH})$ berdasarkan data

energi ikatan jawablah pertanyaan-pertanyaan berikut dengan diskusi secara

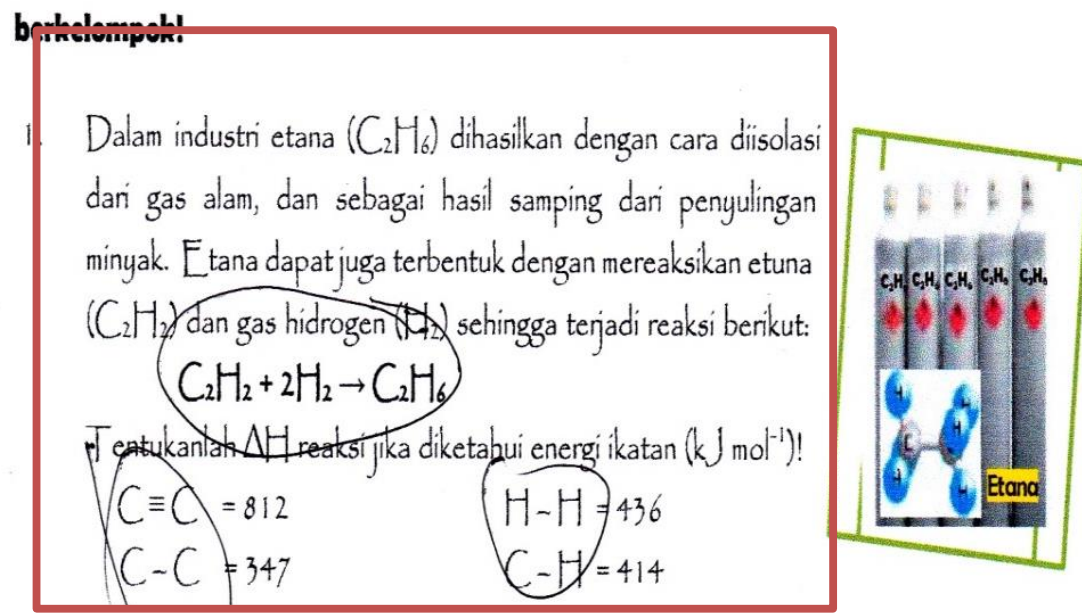

(a)

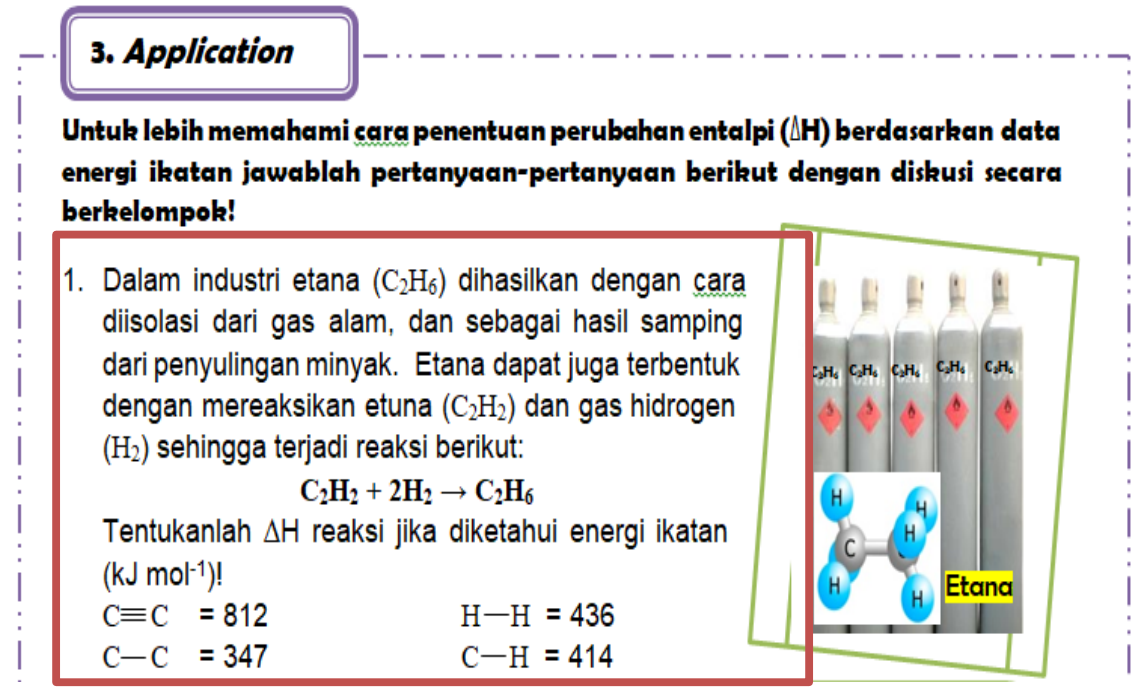

(b)

Gambar 3. Revisi Aspek Kelayakan Kegrafisan (a) Tampilan sebelum revisi dan (b) Tampilan setelah revisi

Contoh tampilan revisi oleh validator materi pada aspek kelayakan karakteristik ICARE terkait perubahan soal pada tahap connection menjadi pertanyaan-pertanyaan yang menghubungkan antara konsep yang telah dipelajari sebelumnya dengan materi yang akan dipelajari oleh peserta didik disediakan pada Gambar 4. 


\section{Connection}

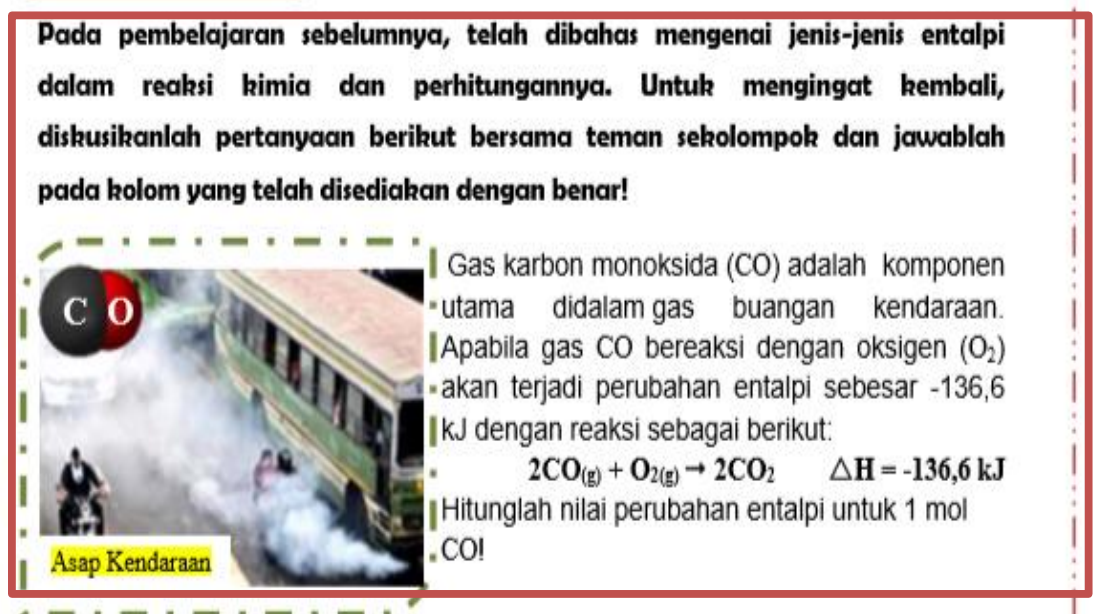

(a)

\section{Connection}

Perhatikan gambar berikut ini!
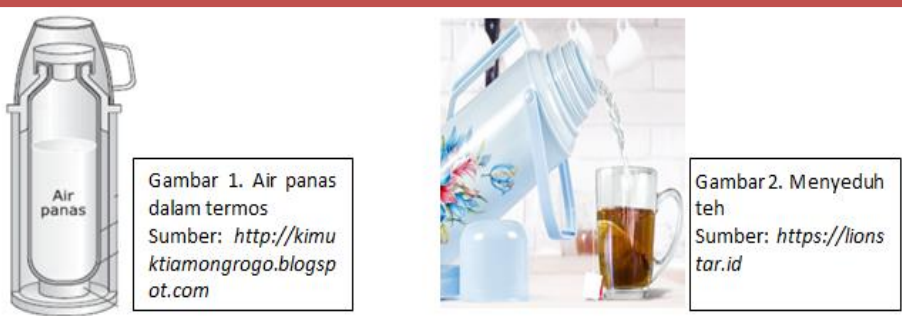

Pada Gambar 1. merupakan sebuah termos yang berisi air panas. Manakah yang merupakan sistem dan lingkungan?

Apabila air dalam termos kita keluarkan untuk membuat teh seperti pada Gambar 2. apakah kalornya dapat diukur?

Jika tidak, apa yang bisa diukur?

(b)

Gambar 4. Revisi Aspek Kelayakan Karakteristik ICARE (a) Tampilan sebelum revisi dan (b) Tampilan setelah revisi

\section{Uji Satu-satu}

Setelah dilakukan validasi, dilaksanakan uji satu-satu dengan tiga orang peserta didik yang telah mempelajari materi penentuan perubahan entalpi dan memiliki kemampuan kompetensi berbeda-beda untuk mengerjakan LKPD yang telah valid oleh validator. Uji satu-satu ini dilakukan guna mendapatkan informasi tentang kejelasan dan kemudahan pengguna terhadap LKPD. Peneliti mencatat waktu yang diperlukan peserta didik dalam mengerjakan LKPD yang telah 
dikembangkan serta mengkoreksi jawaban peserta didik. Rincian waktu dan nilai yang diperoleh dalam pengerjaan LKPD oleh peserta didik disajikan pada Tabel 9.

Tabel 9. Waktu dan Nilai Peserta Didik pada Uji Satu-satu

\begin{tabular}{ccccccc}
\hline \multirow{2}{*}{ LKPD } & \multicolumn{3}{c}{ Waktu (menit) } & \multicolumn{3}{c}{ Nilai } \\
\cline { 2 - 7 } & PD-01 & PD-02 & PD-03 & PD-01 & PD-02 & PD-03 \\
\hline 1 & 41 & 43 & 44 & 76 & 73,3 & 58,6 \\
2 & 43 & 45 & 46 & 97,3 & 82,6 & 78,6 \\
3 & 39 & 42 & 44 & 80 & 87,6 & 84,6 \\
4 & 40 & 43 & 45 & 86,6 & 89,3 & 86,6 \\
\hline Rata-rata & 40,75 & 43,25 & 44,75 & 84,97 & 83,2 & 77,1 \\
\hline
\end{tabular}

Hasil uji satu-satu terhadap 3 orang peserta didik secara keseluruhan menunjukkan bahwa peserta didik yang memperoleh rata-rata nilai tinggi memerlukan waktu pengerjaan LKPD yang lebih sedikit, sedangkan untuk peserta didik dengan perolehan rata-rata nilai rendah memerlukan waktu yang lebih lama. Hal ini didasari oleh perbedaan tingkat kemampuan peserta didik yang tinggi, sedang, dan rendah. Untuk peserta didik berkemampuan tinggi akan lebih cepat dalam mengerjakan LKPD karena telah memiliki pemahaman terhadap materi-materi yang telah dipelajari. Sedangkan peserta didik berkemampuan rendah perlu membaca dan memahami soal berulang kali karena peserta didik berkemampuan rendah cenderung kurang memahami materi-materi yang sudah pernah dipelajari, sehingga terlihat bingung, ragu-ragu dan memerlukan waktu yang cukup lama dalam menjawab soal. Hal ini sesuai dengan penelitian yang dilakukan oleh Paramitha dan Yunianta (2017) yang menyimpulkan bahwa subjek dengan kemampuan tinggi merencanakan penerapan ide dengan produktif dan lancar tanpa mengalami kesulitan yang berarti.

\section{Uji Coba Terbatas}

LKPD yang telah dikembangkan juga diuji coba terbatas kepada 3 orang guru kimia SMA dan 20 orang peserta didik sebagai responden yang bertujuan untuk memperoleh masukan apakah LKPD yang dikembangkan dapat dibaca dengan jelas dan dipahami dengan baik. Peserta didik sebelumnya telah mempelajari materi penentuan perubahan entalpi sehingga peserta didik diharapkan dapat memberikan masukan untuk menilai LKPD yang telah dikembangkan karena telah memiliki pengetahuan dasar tentang materi. Hasil respon pengguna yang diperoleh berada pada kriteria sangat baik dengan rata-rata skor total 3,6 oleh guru sedangkan pada 
peserta didik didapatkan rata-rata skor total 3,45. Berlandaskan respon positif tersebut, didapatkan LKPD berbasis ICARE pada materi penentuan perubahan entalpi yang final. Rekapitulasi data respon pengguna dapat dilihat pada Tabel 10.

Tabel 10. Rekapitulasi Data Respon Pengguna

\begin{tabular}{lccc}
\hline Responden & $\begin{array}{c}\text { Rata-rata } \\
\text { Skor Total }\end{array}$ & $\begin{array}{c}\text { Range Rata- } \\
\text { Rata Skor }\end{array}$ & Kriteria Respon Pengguna \\
\hline Guru & 3,6 & $3,25-4,00$ & Sangat Baik \\
\hline Peserta Didik & 3,45 & $3,25-4,00$ & Sangat Baik \\
\hline
\end{tabular}

Rata-rata skor respon pengguna pada LKPD berbasis ICARE oleh guru dan peserta didik berturut-turut sebesar 3,6 dan 3,45. Penelitian relevan yang dilakukan oeh Suryanti dan Muh Asrullah (2019) hanya melakukan uji respon terhadap peserta didik dengan perolehan skor sebesar 3,44. Berlandaskan respon positif tersebut, didapatkan LKPD berbasis ICARE pada materi penentuan perubahan entalpi yang final.

\section{Kesimpulan}

Pengembangan LKPD berbasis ICARE pada materi penentuan perubahan entalpi untuk SMA/MA telah dinyatakan valid oleh tim validator berdasarkan 5 aspek kelayakan meliputi kelayakan isi, karakteristik ICARE, kebahasaan, penyajian dan kegrafisan dengan persentase kelayakan berturut-turut sebesar 92,59\%, 96,67\%, $95 \%, 97,22 \%$, dan 95,83\% dan diperoleh rata-rata sebesar 95,46\% dengan kategori kelayakan valid, sehingga LKPD yang telah dikembangkan layak digunakan dalam proses pembelajaran. Respon pengguna berada pada kriteria sangat baik dengan rata-rata skor total sebesar 3,6 oleh guru dan 3,45 oleh peserta didik.

\section{Daftar Referensi}

Almubarak, M., \& Hikmah, N. (2019). Implementasi Model Pembelajaran ICARE Terhadap Keterampilan Proses Sains pada Materi Larutan Elektrolit dan Non Elektrolit. Junal Penelitian Pendidikan IPA. 5(1): 92-97.

Paramitha, N., \& Yunianta, T. N. H. (2017). Analisis Proses Berpikir Kreatif dalam Memecahkan Masalah Matematika Matri Aritmatika Sosial Siswa SMP Berkemampuan Tinggi. Jurnal Mitra Pendidikan. 1(10): 983-994.

Plomp, T. (2013). Educational Design Research: an Introduction. Netherlands Institute for Curriculum Development. Enschede. 
Prastowo, A. (2013). Panduan Kreatif Membuat Bahan Ajar Inovatif. Yogyakarta: Diva Press.

Rawa, N. R., Sutawidjaja, A., \& Sudirman. (2016). Pengembangan Perangkat Pembelajaran Berbasis Model Learning Cycle-7E Pada Materi Trigonometri Untuk Meningkatkan Kemampuan Koneksi Matematis Siswa. Jurnal Pendidikan. 1(6): 1042-1055.

Riduwan. (2012). Skala Pengukuran Variabel-Variabel Penelitian. Bandung: Alfabeta.

Rochmad. (2012). Desain Model Pengembangan Perangkat Pembelajaran Matematika. Jurnal Kreano. 3(1): 59-72.

Suryanti \& Asrullah, M. (2019). Pengembangan Lembar Kerja Siswa (LKS) Berbasis ICARE Pada Mata Pelajaran Matematika Siswa. Jurnal Pendidikan Matematika. 3(2): 228-239.

Supangat, A. (2014). Statistika: Dalam Kajian Deskriptif, Inferensi dan Nonparametrik. Jakarta: Prenada Media Group.

Wahyudin, D. (2010). Model Pembelajaran ICARE Pada Kurikulum Mata Pelajaran TIK di SMP. Jurnal Penelitian Pendidikan. 11(1): 23-33.

Widoyoko, E. P. (2017). Teknik Penyusunan Instrumen Penilaian. Yogyakarta: Pustaka Belajar. 